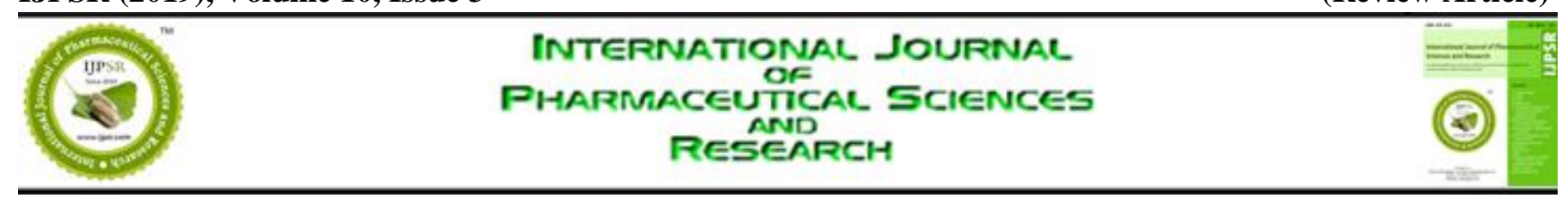

Received on 14 July 2018; received in revised form, 12 October 2018; accepted, 16 October 2018; published 01 March 2019

\title{
ALZHEIMER'S DISEASE: A COMPREHENSIVE REVIEW
}

\author{
Surabhi and B. K. Singh *
}

Department of Pharmaceutical Sciences, Kumaun University, Nainital - 263001, Uttarakhand, India.

Keywords:

Alzheimer's disease, Pathology, Risk factors, Protective factors, Biomarkers, Pharmacotherapy

\section{Correspondence to Author:}

Dr. B. K. Singh

Head and Dean,

Department of Pharmaceutical

Sciences, Kumaun University,

Bhimtal Campus, Bhimtal - 263136,

Uttarakhand, India.

E-mail: bksinghku@gmail.com
ABSTRACT: Alzheimer disease (AD) is the most common cause of dementia which affects more than 44 million individuals worldwide. It has been noticed that there is only symptomatic treatments are available to treat $\mathrm{AD}$, but no cure exists. It is a neurodegenerative disease characterized by Alois Alzheimer's in 1906, and neurodegenerative diseases are one of the major concerns facing by the modern health care system. It is a multifarious complex disease which pathology not clearly understood but it is generally characterized by neuronal damage, memory dysfunction, etc. main pathological hallmark factor for Alzheimer disease is deposition of amyloid- $\beta(\mathrm{A} \beta)$ plaques around the neurons, neurofibrillary tangles, and a decrease in acetylcholine concentration and some other neurotransmitter dysregulation. Different types of risk factors like oxidative stress, obesity, diabetes, hypertension, air pollution, smoking, hyper cholesterolemia etc. have a very significant role in the development of $\mathrm{AD}$ and in the development of its preventive measures. Physical exercise and nutritional factors have been shown as protective measures for it and help in its prevention. For the diagnosis of it, we use cerebrospinal fluid biomarkers and positron emission tomography etc. Currently, there are two conventional pharmacotherapies exist for $\mathrm{AD}$ which is approved by Food and Drug Administration (FDA) are respectively- acetylcholinesterase inhibitors- tacrine, donepezil, rivastigmine, galantamine and N-methyl-D-aspartate glutamate antagonist (NMDA)-memantine.
INTRODUCTION: Alois Alzheimer primarily described Alzheimer disease (AD) in 1906s as a progressive and neurodegenerative disorder. Neurodegenerative disorders are one of the crucial problems facing by the modern health care system, and Alzheimer disease is one of those.

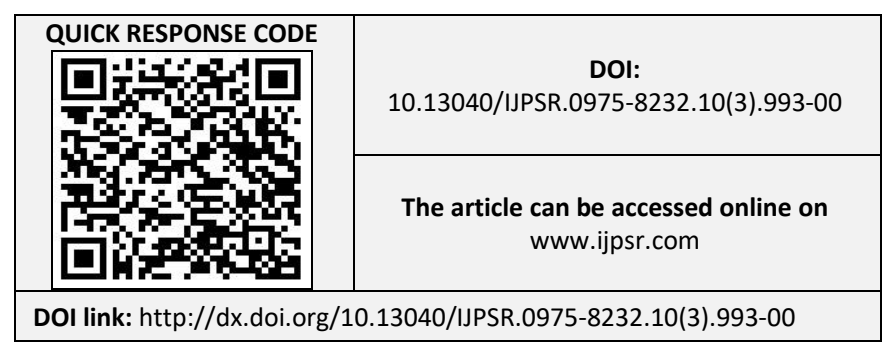

It is identified as the most ubiquitous form of dementia among geriatric persons from the very beginning of twenty-first century ${ }^{1}$. Alzheimer disease is the most common cause of dementia, worldwide it generally comprises around 60-80\% of all dementia events ${ }^{2}$, and is characterized by progressive loss of neurons, brain functions and cognition function ${ }^{3}$.

Epidemiology: As on today, more than 36.5 million persons are living with $\mathrm{AD}$, and this may increase in 2030 to 65.7 million and in 2050 to 115.4 million. It is estimated by the World Health Organization (WHO) that more than $50 \%$ of people 
in developing countries are living with $\mathrm{AD}$ and it can go up to $70 \%$ by $2025 .^{4}$

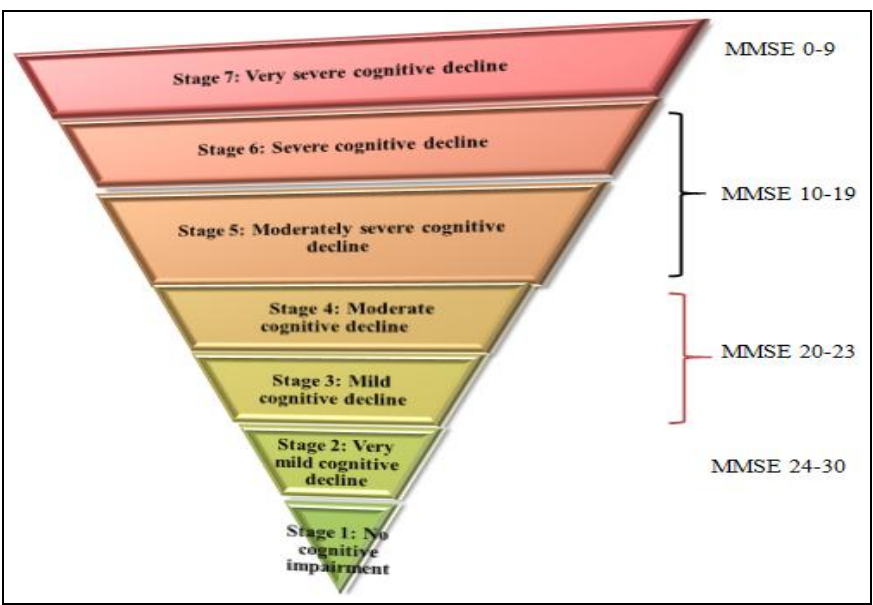

FIG. 1: DIFFERENT STAGES OF AD. All seven stages are displayed in the increasing order of severity in the inverted pyramid, further correlated with MMSE scores. MMSE score in AD patients decreases with the advancement in $\mathrm{AD}$ stage. $\mathrm{AD}$, Alzheimer's disease; MMSE, Mini-Mental State Examination ${ }^{5}$.

Pathology: Pathology of Alzheimer disease is not clearly understood yet because it is a polygenic and multifarious complex disease ${ }^{6,7}$.
Some important neuropathological hallmarks which characterized Alzheimer's disease are as follows:

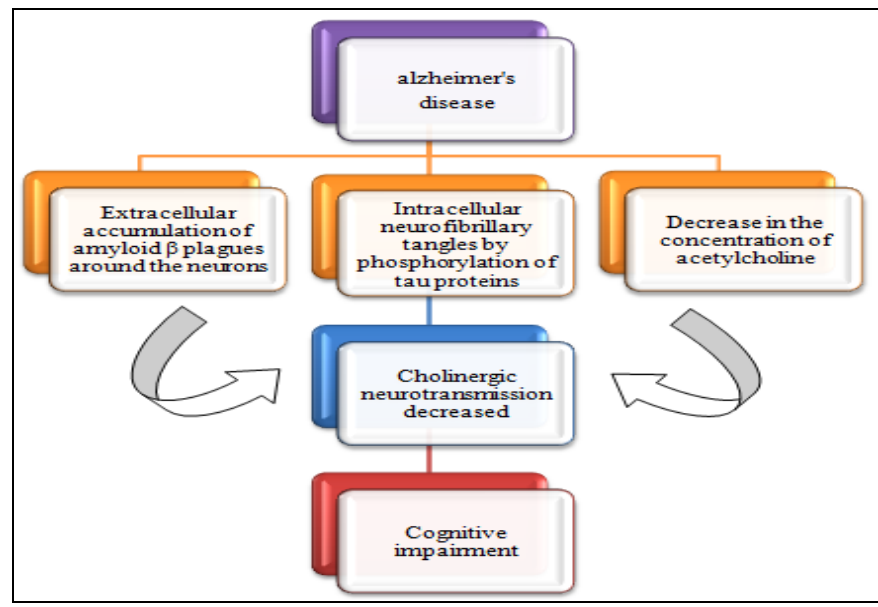

\section{FIG. 2: SOME IMPORTANT ALZHEIMER'S PATHOLOGIC CONDITIONS ${ }^{1,8,9}$}

Alzheimer disease mainly characterized by progressive accumulation of amyloid- $\beta$ (A $\beta)$ proteins around the neurons which form plagues, the formation of neurofibrillary tangles (NFTs) by the hyperphosphorylation of tau proteins and a decrease in the level of ACh neurotransmitter ${ }^{10}$.

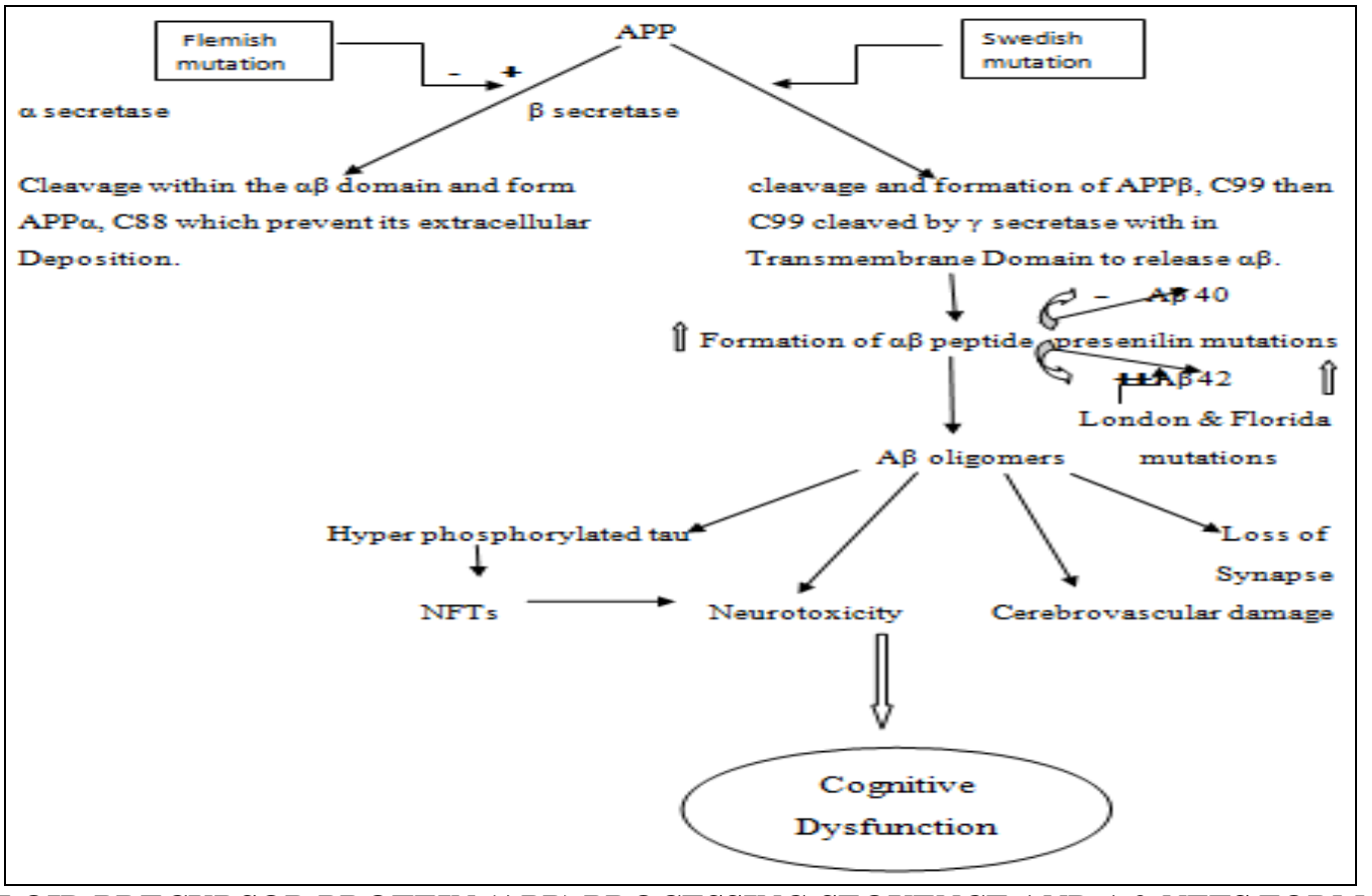

FIG. 3: AMYLOID PRECURSOR PROTEIN (APP) PROCESSING SEQUENCE AND A $\beta$, NFTS FORMATION ${ }^{6,11-13}$

Acetylcholine is a neurotransmitter; which is synthesized from cholinergic neurons of the brain and helps in the signal transmission and delivery of messages in the brain ${ }^{14,15}$. It shows a very crucial part in learning and memory ${ }^{16,17}$. AD pathology relates to the deposition of plaques and neurofibrillary tangles (NFTs) in the brain which leads to degradation of the cholinergic neurons in the hippocampal and cortical part of the brain and decrease in the level of acetylcholine ${ }^{18,19,20,21,22}$. Cholinergic dysfunction is responsible for unregulated signal transmission of the cholinergic 
pathway which is accompanied by $\mathrm{AD}{ }^{23}$. Dysfunction in cholinergic regulations originating from the basal forebrain and interact with pathological aspects of $\mathrm{AD}$-like $\mathrm{A} \beta$ plague, NFTs, inflammation, oxidative stress to impair cognition ${ }^{24}$.

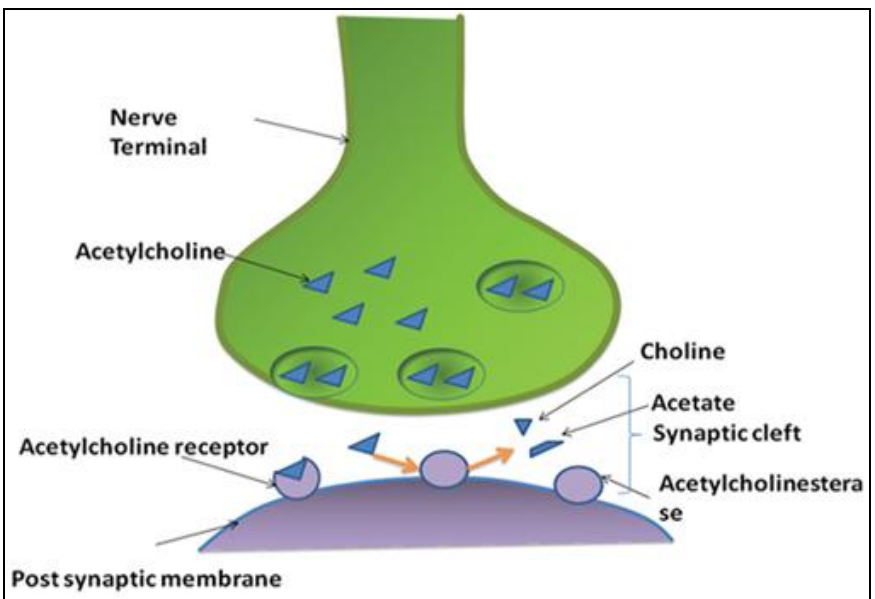

FIG. 4: ACETYLCHOLINESTERASE MECHANISM OF ACTION IN ALZHEIMER'S DISEASE ${ }^{4}$

Degradation of the neuronal pathway also alter the function of some other serotonergic, dopaminergic, glutamatergic, and adrenergic neurons by which neurotransmitters like dopamine, serotonin, glutamine and noradrenaline dysregulation occur, and it's also accompanied by AD progression ${ }^{25}$.

\section{Risk Factors:}

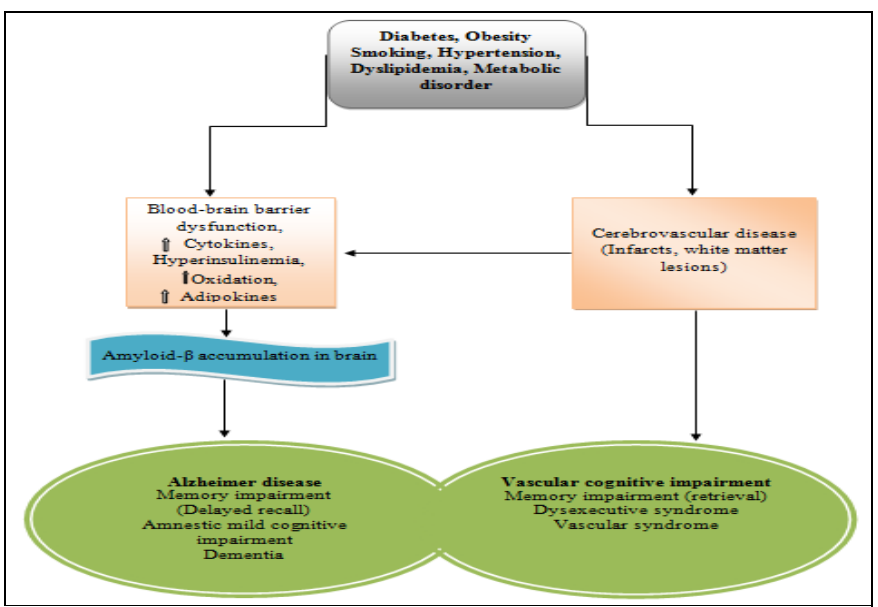

FIG. 5: VARIOUS RISK FACTORS FOR AD AND THEIR CONSEQUENCES ${ }^{26,27}$

There are various genetic, environmental and dietary risk factors for Alzheimer disease like diabetes, oxidative stress, hypertension, air pollution, hypercholesterolemia, atrial fibrillation, alcohol, smoking, etc. These risk factors have played a very significant role in the development of Alzheimer's preventive measures ${ }^{28}$.
Diabetes: Insulin-degrading enzyme works as a cleavage enzyme for insulin and amyloid $\beta$. In type 2 diabetes due to a decrease in insulin signaling, production of insulin-degrading enzyme decreased, and it leads to $\mathrm{A} \beta$ accumulation and hyperinsulinemia $^{29}$. It is also found that insulin and amyloid- $\beta$ competing for insulin-degrading enzyme and the clearance of $\mathrm{A} \beta$ decreased ${ }^{30}$. It is also hypothesized that insulin regulates phosphorylation of tau proteins ${ }^{31}$, and they all show a central load for the pathogenesis of Alzheimer disease.

Hypertension: It may elevate the risk of $\mathrm{AD}$ through reducing the blood-brain barrier (BBB) vascular integrity, which may result into the protein extravasation in brain tissues and leads to accumulation of $\mathrm{A} \beta{ }^{32,33,34}$. Hypertension is also referred to as a risk factor for different pathological conditions like myocardial infarctions, strokes, ischemic white matter lesions, atherosclerosis, and cardiovascular diseases, etc. these all are also connected to $\mathrm{AD}^{35}$. According to a study increases midlife systolic blood pressure ( $\geq 160 \mathrm{mmHg}$ ) is connected with higher number of senile plaques and lesser weight of the brain in hippocampus and neocortex and increased in diastolic blood pressure $(\geq 95 \mathrm{mmHg}$ ) is related to increase in the numbers of neurofibrillary tangles in hippocampus of the brain in late life ${ }^{36}$.

Obesity: As per studies it is noticed that higher cholesterol and saturated fats enhance the risk of $\mathrm{AD}{ }^{37}$. Obesity is characterized by a chronic moderate systemic inflammation, which leads to a brain inflammatory process and initially characterized by increased cytokines secretion 38,39 . It is a pro-inflammatory factor, and cytokines which are primarily involved in it are tumor necrosis factor alpha (TNF $\alpha)$, interleukin-1beta $($ IL-1 $\beta)$, chemokine and interleukin-6 (IL-6) ${ }^{40}$.

Oxidative Stress: In several studies, oxidative stress seems to be playing a damaging effect on the generation of $\mathrm{AD}^{41,42}$. Oxidative stress leads to the unlimited production of reactive oxygen species like superoxide, hydrogen peroxide, hydroxyl radicals, nitric oxide radical's, etc. ${ }^{43}$ It is related to oxidative damage of nucleic acids, protein, lipid, and carbohydrates by oxidation of these components 10, 44, 45. There are several sources which are involved in the production of reactive 
oxygen species (ROS) such as endogenous sources like mitochondria, cytochrome $\mathrm{P} 450$, peroxisomes, etc. antioxidant defenses like vitamins (A,C and E), glutathione peroxidase, catalase, glutathione, and exogenous sources like UV, ionizing radiations, inflammatory cytokines etc. ${ }^{46}$

\section{Protective Factors:}

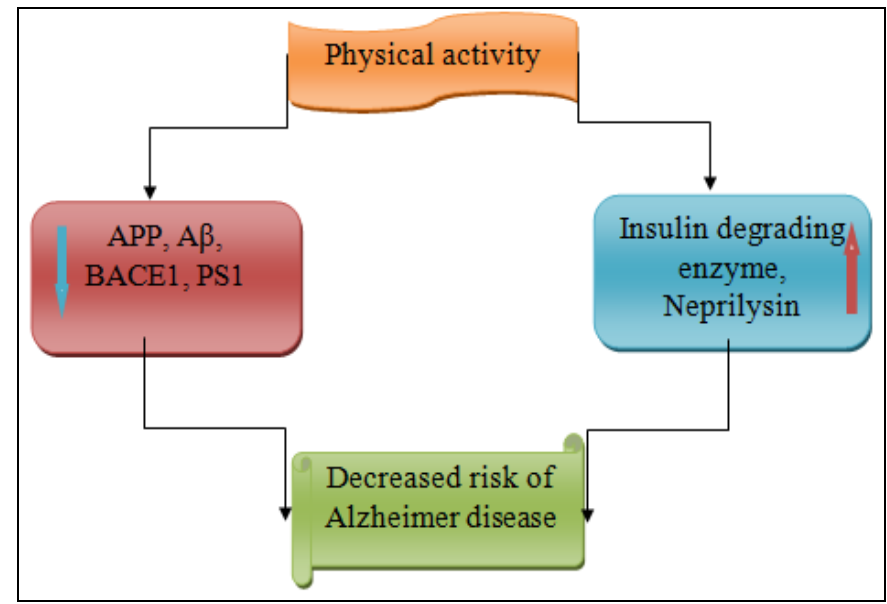

FIG. 6: PHYSICAL ACTIVITY AND THROUGH IT PREVENTION OF AD ${ }^{47}$

Physical Exercise: Several pieces of evidence show that consistently aerobic exercise boost up cognitive performance ${ }^{48}$, and considered as an effective preventive strategy for the treatment of different stages of $\mathrm{AD}{ }^{49}$. It is studied that physical activity works as an enhancement factor for neurotrophic factors like brain-derived neurotrophic factor (BNDF) amount, and their neuroprotective action gives a beneficial effect in $\mathrm{AD}$ by improving cognition 50 . Routine exercise also works as a conditioner for oxidative stress and reactive oxygen species (ROS), through reducing ROS produced protein damage, it gives a protective effort in neurodegeneration and AD ${ }^{51,52}$. Physical exercise also decreases the level of tumor necrosis factor alpha (TNF- $\alpha$ ), interleukin-1 alpha (IL-1 $\alpha$ ) which leads to decrease in the amyloid- $\beta$ produced neuroinflammation of the brain and gives a protective effect in cognition or dementia ${ }^{53}$. It also intensity the level of nitric oxide by the increase of endothelial nitric oxide synthase action in the brain, which leads to improve in the neuronal blood flow and brain damage ${ }^{54}$.

Neprilysin (NEP) and insulin degrading enzymes (IDE) are cleavage enzymes which regulate and determine the amount of amyloid- $\beta$ deposition and prevent the neurons from amyloid- $\beta$ toxicity 55,56 , 57 . Physical exercise induces IDE and NEP action by which $\mathrm{A} \beta$ accumulation doesn't occur which is hypothesized the most important factor for Alzheimer's pathology.

Nutritional Factor: Nutritional factor appears to play an important role as a protective factor for $\mathrm{AD}$ ${ }^{58}$. It is reported that if we take a diet which is very rich in cholesterol, carbohydrates, and fats, results show a very detrimental role in $\mathrm{AD}^{59}$. It is found that if we intake of dietary vitamin $\mathrm{E}$ but do not take extra vitamin E supplements, it is associated with decreased risk of $\mathrm{AD}{ }^{60}$. Insufficiency of folate, vitamin $\mathrm{B} 6$ and vitamin $\mathrm{B}_{12}$ outcomes into the increase in the homocysteine level and homocysteine increases concentration related to the $\mathrm{AD}$ as a neurotoxin ${ }^{61}$.

Biomarkers for AD: The role of biomarkers in the screening of $\mathrm{AD}$ becomes very significant, from the point of view accuracy, sensitivity, and specificity of the diagnosis ${ }^{62}$.

\section{Cerebro Spinal Fluid (CSF) Biomarkers:} Amyloid- $\beta$ and tau proteins deposition are considered for AD pathology. In the CSF low amount of $\mathrm{A} \beta$ and a higher amount of total tau and phosphorylated tau (P-tau) proteins are supposed as a marker for $\mathrm{AD}$ diagnosis ${ }^{63} \mathrm{~A} \beta$ indicated decreased clearance of amyloid- $\beta$ from the brain to the CSF or blood ${ }^{64}$, the high amount of P-tau exhibits neurofibrillary tangles generation in the brain, and total tau showed neuronal damage ${ }^{65,66}$.

Positron Emission Tomography (PET): It is used as a neuroimaging method in which various radiotracers are used for the visualization of cerebral activity and $\mathrm{A} \beta$ accumulation ${ }^{67}$.

PET- A $\beta$ imaging marker is used to estimate the accumulation of amyloid- $\beta$ in fibrillary form 68,69 ${ }^{11} \mathrm{C}$-PIB is used as an amyloid- $\beta$ marker in PET technology; AD patient shows higher retention of ${ }^{11} \mathrm{C}$-PIB in the cortical regions which is spotted by amyloid- $\beta$ depositions ${ }^{70,71,72}$. ${ }^{18} \mathrm{~F}$-FDG-PET is generally used for the checking of cerebral metabolism by using ${ }^{18}$ F-FDG as a marker. Reduced fluorodeoxyglucose uptake or decrease in glucose metabolism seems on PET in temporoparietal areas showed the AD occurrence and cerebral dysfunction $73,74,75$. 
Pharmacotherapy: Currently available conventional pharmacotherapy for $\mathrm{AD}$ which is approved by the Food and Drug Administration (FDA) are mainly of two types:

- Acetylcholinesterase inhibitors - tacrine, donepezil, rivastigmine, galantamine

- N-methyl-D-aspartate glutamate antagonist (NMDA antagonist)- memantine

Acetylcholinesterase Inhibitors: According to cholinergic hypothesis cognitive dysfunction occurs in $\mathrm{AD}$ patients due to extensive loss of cholinergic neurons, enzymatic dysfunction for ACh synthesis and degradation which leads to an inability to neurologic impulses transmission across cholinergic synapses 76,77 . So for enhancing the cholinergic transmission, AChEIs has been proposed, which delay the degradation of ACh between synapses ${ }^{78}$. They also act by reducing levels of the amyloid $\beta$ protein precursor, amyloid $\beta$ production and accumulation ${ }^{79}$. Till date, four AChEIs are developed and approved by the FDA (Tacrine, donepezil, rivastigmine, and galantamine) for the treatment of different stages of AD.

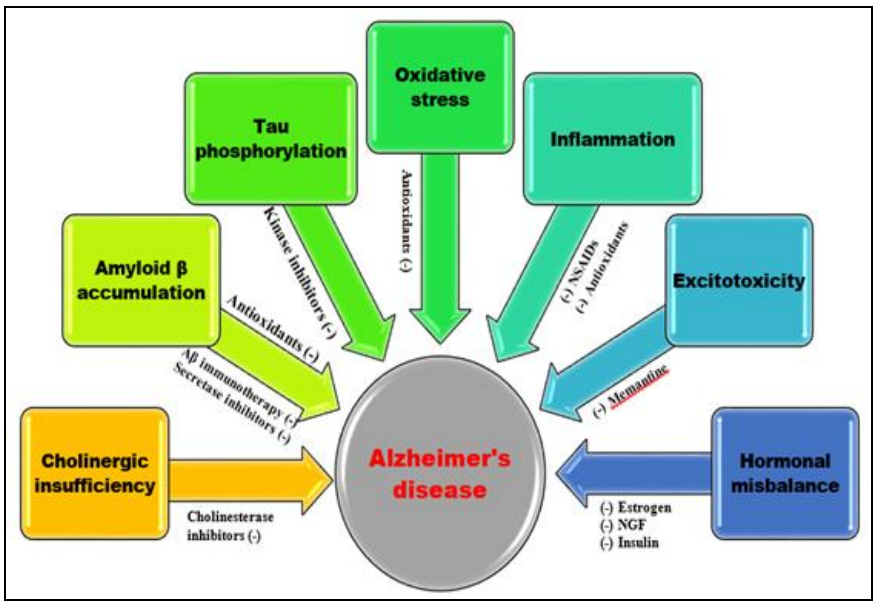

FIG. 7: SUMMARY OF PHARMACOTHERAPEUTIC TARGETS FOR ALZHEIMER'S DISEASE ${ }^{80}$

N-methyl -D- aspartate Glutamate Antagonist (NMDA Antagonist): NMDA receptors appear as a promising target for prevention of progressive neurodegeneration in $A D^{81}$. Because N-methyl-Daspartate glutamate (NMDA) receptor overactivation allows excessive $\mathrm{Ca}^{2+}$ influx which causes excitotoxicity and leads to damage and loss of neurons ${ }^{82}$. So in recent years, NMDAantagonist is recognized as a new hope for the treatment of $\mathrm{AD}$. Memantine is a first NMDA receptor blocker which is approved by the FDA for the treatment of moderate to severe $\mathrm{AD}{ }^{83}$.

\section{CONCLUSION AND FUTURE ASPECTS:}

Alzheimer's disease is a progressive neurodegenerative disease which is spreading very quickly throughout the world. Due to its complex pathology, variable symptoms and unspecific diagnosis the present therapies like acetylcholinesterase inhibitors (tacrine, donepezil, rivastigmine, galantamine) and glutamate antagonist (memantine) give only symptomatic relief and modest efficacy, so there is no cure of it exist till yet. In the recent time, there is a rapid increment occurs in the knowledge about AD etiology and its underlying pathophysiological process so research in this field have the very vast scope and the cure for it does not appear so far.

Nowadays lots of studies were performed to find the cure for $\mathrm{AD}$. In recent time there are various promising investigations are undergoing with some new possibilities like the drugs which target amyloid- $\beta$ in different manners. Some current ongoing research approaches for $\mathrm{AD}$ are like $\alpha$ secretase promotors, $\gamma$-secretase inhibitors, $\beta$ secretase inhibitors, immunotherapy (anti-amyloid antibodies), etc. So, in the upcoming years, with lots of significant advancements in the novel therapeutic agents will empower us to provide more comprehensive and distinctive pharmacotherapy for Alzheimer's disease.

ACKNOWLEDGEMENT: The authors wish to thank the whole Management of Department of Pharmaceutical Sciences, Kumaun University, Bhimtal Campus, Nainital and Mr. Navdeep Pandey (Assistant Professor) for their constant support and motivation.

\section{CONFLICT OF INTEREST: Nil}

\section{REFERENCES:}

1. Anand A, Patience AA, Sharma N and Khurana N: The present and future of pharmacotherapy of Alzheimer's disease: A comprehensive review. European Journal of Pharmacology 2017; 815: 364-365.

2. Gustavsson A, Green C, Jones RW, Förstl H, Simsek D, de Vulpillieres FDR, Luthman S, Adlard N, Bhattacharyya S and Wimo A: Current issues and future research priorities for health economic modeling across the full continuum of Alzheimer's disease. Alzheimer's \& Dementia: the Journal of the Alzheimer's Association 2017; 13(3): 312-321. 
3. Alzheimer's Association: Alzheimer's disease facts and figures. Alzheimer's \& Dementia 2018; 14(3): 367-429.

4. Panche AR, Chandra S, Diwan A and Harke SA: Alzheimer's and current therapeutics: A review. Asian J Pharm Clin Res 2015; 8(3): 14-19.

5. Bhardwaj D, Mitra C, Narasimhulu CA, Riad A, Doomra $\mathrm{M}$ and Parthasarathy S: Alzheimer's disease-current status and future directions. Journal of Medicinal Food 2017; 20(12): 1141-1151.

6. Huang X, Moir RD, Tanzi, RE, Bush AI and Rogers JT: Redox-active metals, oxidative stress, and Alzheimer's disease pathology. Annals of the New York Academy of Sciences 2004; 1012(1): 153-163.

7. Godyń J, Jończyk J, Panek D and Malawska B: Therapeutic strategies for Alzheimer's disease in clinical trials. Pharmacological Reports 2016; 68(1): 127-38.

8. Kumar A and Singh A: A review on Alzheimer's disease pathophysiology and its management: an update. Pharmacological Reports 2015; 67(2): 195-203.

9. Kumar A, Nisha C, Silakari C, Sharma I, Anusha K, Gupta $\mathrm{N}$, Nair P, Tripathi T and Kumar A: Current and novel therapeutic molecules and targets in Alzheimer's disease. Journal of the Formosan Medical Association 2016; 115(1): 3-10.

10. Mecocci P, Boccardi V, Cecchetti R, Bastiani P, Scamosci $\mathrm{M}$, Ruggiero $\mathrm{C}$ and Baroni $\mathrm{M}$ : A Long journey into aging, brain aging, and alzheimer's disease following the oxidative stress tracks. Journal of Alzheimer's Disease 2018; 62(3): 1319-1335.

11. Hardy J: Amyloid, the presenilins and Alzheimer's disease. Trends in Neurosciences 1997; 20(4): 154-159.

12. Imbimbo BP, Lombard $\mathrm{J}$ and Pomara $\mathrm{N}$ : Pathophysiology of Alzheimer's disease. Neuroimaging Clinics 2005; 15(4): 727-753.

13. Schelterns $\mathrm{P}$ and Feldman H: Treatment of Alzheimer's disease; current status and new perspectives. The Lancet Neurology 2003; 2(9): 539-547.

14. Ferreira-Vieira HT, Guimaraes MI, Silva RF and Ribeiro MF: Alzheimer's disease: targeting the cholinergic system. Current Neuropharmacology 2016; 14(1): 101-115.

15. Pope $\mathrm{CN}$ and Brimijoin S: Cholinesterases and the fine line between poison and remedy. Biochemical Pharmacology 2018; 19: 433-446.

16. Blokland A: Acetylcholine: A neurotransmitter for learning and memory?. Brain Research Reviews 1995; 21(3): 285-300.

17. Francis PT, Palmer AM, Snape M and Wilcock GK: The cholinergic hypothesis of Alzheimer's disease: a review of progress. Journal of Neurology, Neurosurgery \& Psychiatry 1999; 66(2): 137-147.

18. Arendt T, Brückner MK, Morawski M, Jäger C and Gertz HJ: Early neuron loss in Alzheimer's disease: cortical or subcortical?. Acta Neuropathological Communications 2015; 3(1): 10 .

19. Carter J and Lippa CF: $\beta$-Amyloid, neuronal death and Alzheimer's disease. Current Molecular Medicine 2001; 1(6): 733-737.

20. Geula C and Mesulam M: Cholinesterases and the pathology of Alzheimer disease. Alzheimer Disease and Associated Disorders 1995; 9(2): 23-28.

21. Lombardo $\mathrm{S}$ and Maskos $\mathrm{U}$ : Role of the nicotinic acetylcholine receptor in Alzheimer's disease pathology and treatment. Neuropharmacology 2015; 96: 255-262.

22. Paul S, Jeon WK, Bizon JL and Han JS: Interaction of basal forebrain cholinergic neurons with the glucocorticoid system in stress regulation and cognitive impairment. Frontiers in Aging Neuroscience 2015; 7(43): 1-11.
23. Kihara $\mathrm{T}$ and Shimohama S: Alzheimer's disease and acetylcholine receptors. Acta Neurobiologiae Experimentalis 2004; 64(1): 99-106.

24. Muir JL: Acetylcholine, aging, and Alzheimer's disease. Pharmacology Biochemistry and Behavior 1997; 56(4): 687-696.

25. Hampel H, Mesulam MM, Cuello AC, Farlow MR, Giacobini E, Grossberg GT, Khachaturian AS, Vergallo A, Cavedo E, Snyder PJ and Khachaturian ZS: The cholinergic system in the pathophysiology and treatment of Alzheimer's disease. Brain 2018; 141(7): 1917-1933.

26. Reitz C and Mayeux R: Alzheimer disease: epidemiology, diagnostic criteria, risk factors and biomarkers. Biochemical Pharmacology 2014; 88(4); 640-651.

27. Reitz C, Brayne $\mathrm{C}$ and Mayeux R: Epidemiology of Alzheimer disease. Nature Reviews Neurology 2011; 7(3): 137.

28. Dominguez E, Chin TY, Chen $\mathrm{CP}$ and $\mathrm{Wu} \mathrm{TY}$ : Management of moderate to severe Alzheimer's disease: Focus on memantine. Taiwanese Journal of Obstetrics and Gynecology 2011; 50(4): 415-423.

29. Imtiaz B, Tolppanen AM, Kivipelto $\mathbf{M}$ and Soininen H: Future directions in Alzheimer's disease from risk factors to prevention. Biochemical Pharmacology 2014; 88(4): 661-670.

30. Hickman RA, Faustin A and Wisniewski T: Alzheimer disease and its growing epidemic: risk factors, biomarkers, and the urgent need for therapeutics. Neurologic Clinics 2016; 34(4): 941-953.

31. Arvanitakis Z, Wilson, RS, Bienias, JL, Evans DA and Bennett DA: Diabetes mellitus and risk of Alzheimer disease and decline in cognitive function. Archives of Neurology 2004; 61(5): 661-666.

32. Deane R, Wu Z and Zlokovic BV: RAGE (yin) vs. LRP (yang) balance regulates Alzheimer amyloid $\beta$-peptide clearance through transport across the blood-brain barrier. Stroke 2004; 35(11): 2628-2631.

33. Kalaria RN: Vascular basis for brain degeneration: faltering controls and risk factors for dementia. Nutrition Reviews 2010; 68(2): S74-S87.

34. Luchsinger JA, Reitz C, Honig LS, Tang MX, Shea S and Mayeux R: Aggregation of vascular risk factors and risk of incident Alzheimer disease. Neurology 2005; 65(4): 545551.

35. Skoog I and Gustafson D: Update on hypertension and Alzheimer's disease. Neurological Research 2006; 28(6): 605-611.

36. Petrovitch H, White LR, Izmirilian G, Ross GW, Havlik RJ, Markesbery W, Nelson J, Davis DG, Hardman, J, Foley DJ and Launer LJ: Midlife blood pressure and neuritic plaques, neurofibrillary tangles, and brain weight at death: the HAAS. Neurobiology of Aging 2000; 21(1): 57-62.

37. Povova J, Ambroz P, Bar M, Pavukova V, Sery O, Tomaskova $\mathrm{H}$ and Janout V: Epidemiological of and risk factors for Alzheimer's disease: A review. Biomedical Papers of the Medical Faculty of Palacky University in Olomouc 2012; 156(2): 57-62.

38. Gregor MF and Hotamisligil GS: Inflammatory mechanisms in obesity. Annual Review of Immunology 2011; 29: 415-445.

39. Lumeng $\mathrm{CN}$ and Saltiel AR; Inflammatory links between obesity and metabolic disease. The Journal of Clinical Investigation 2011; 121(6): 2111-2117.

40. Alford S, Patel D, Perakakis N and Mantzoros CS: Obesity as a risk factor for Alzheimer's disease: weighing the evidence. Obesity Reviews 2018; 19(2): 269-280. 
41. Tramutola A, Lanzillotta C, Perluigi M and Butterfield DA: Oxidative stress, protein modification and Alzheimer disease. Brain Research Bulletin 2017; 133: 88-96.

42. Barnham KJ, Masters CL and Bush AI: Neurodegenerative diseases and oxidative stress. Nature Reviews Drug Discovery 2004; 3(3): 205.

43. Mecocci P, Boccardi V, Cecchetti R, Bastiani P, Scamosci $\mathrm{M}$, Ruggiero $\mathrm{C}$ and Baroni $\mathrm{M}$ : A long journey into aging, brain aging, and Alzheimer's disease following the oxidative stress tracks. Journal of Alzheimer's Disease 2018; 62(3): 1319-1335.

44. Mariani E, Polidori MC, Cherubini A and Mecocci P: Oxidative stress in brain aging, neurodegenerative and vascular diseases: an overview. Journal of Chromatography B 2005; 827(1); 65-75.

45. Markesbery WR: Oxidative stress hypothesis in Alzheimer's disease. Free Radical Biology and Medicine 1997; 23(1): 134-147.

46. Finkel $\mathrm{T}$ and Holbrook NJ: Oxidants, oxidative stress and the biology of aging. Nature 2000; 408(6809): 239.

47. Ebrahimi K, Majdi A, Baghaiee B, Hosseini SH and Sadigh-Eteghad S: Physical activity and beta-amyloid pathology in Alzheimer's disease: A sound mind in a sound body. EXCLI Journal 2017; 16: 959.

48. Sacco G, Caillaud C, Ben Sadoun G, Robert P, David R and Brisswalter $\mathrm{J}$ : Exercise plus cognitive performance over and above exercise alone in subjects with mild cognitive impairment. Journal of Alzheimer's Disease 2016; 50(1): 19-25.

49. Cass SP: Alzheimer's disease and exercise: A literature review. Curr Sports Medicine Reports 2017; 16(1): 19-22.

50. Erickson KI, Miller DL and Roecklein KA: The aging hippocampus: interactions between exercise, depression, and BDNF. The Neuroscientist 2012; 18(1): 82-97.

51. Majdi A, Mahmoudi J, Sadigh-Eteghad S, Golzari SE, Sabermarouf B and Reyhani-Rad S: Permissive role of cytosolic $\mathrm{pH}$ acidification in neurodegeneration: a closer look at its causes and consequences. Journal of Neuroscience Research 2016; 94(10); 879-887.

52. Radak Z, Kumagai S, Taylor AW, Naito H and Goto S: Effects of exercise on brain function: Role of free radicals. Applied Physiology, Nutrition and Metabolism 2007; 32(5): 942-946.

53. Kang EB, Kwon IS, Koo JH, Kim EJ, Kim CH, Lee J, Yang $\mathrm{CH}$, Lee YI, Cho, IH and Cho JY: Treadmill exercise represses neuronal cell death and inflammation during $\mathrm{A} \beta$-induced ER stress by regulating unfolded protein response in aged presenilin 2 mutant mice. Apoptosis 2013; 18(11): 1332-1347.

54. Endres M, Gertz K, Lindauer U, Katchanov J, Schultze J, Schröck H, Nickenig G, Kuschinsky W, Dirnagl U and Laufs U: Mechanisms of stroke protection by physical activity. Annals of Neurology 2003; 54(5): 582-590.

55. El-Amouri SS, Zhu H, Yu J, Gage FH, Verma IM and Kindy MS: Neprilysin protects neurons against $\mathrm{A} \beta$ peptide toxicity. Brain Research 2007; 1152: 191-200.

56. El-Amouri SS, Zhu H, Yu J, Marr R, Verma IM and Kindy MS: Neprilysin: an enzyme candidate to slow the progression of Alzheimer's disease. The American Journal of Pathology 2008; 172(5): 1342-1354.

57. Miners JS, Baig S, Palmer J, Palmer LE, Kehoe PG and Love $\mathrm{S}$ : Symposium: Clearance of $\mathrm{A} \beta$ from the Brain in Alzheimer's disease: A $\beta$-Degrading enzymes in Alzheimer's disease. Brain Pathology 2008; 18(2): 240252.

58. Nourhashémi F, Gillette-Guyonnet S, Andrieu S, Ghisolfi A, Ousset PJ, Grandjean H, Grand A, Pous J, Vellas B and
Albarède JL: Alzheimer disease: protective factors. The American Journal of Clinical Nutrition 2000; 71(2): 643649.

59. Yusufov M, Weyandt LL and Piryatinsky I: Alzheimer's disease and diet: A systematic review. International Journal of Neuroscience 2017; 127(2): 161-175.

60. Morris MC, Evans DA, Bienias JL, Tangney CC, Bennett DA, Aggarwal N, Wilson RS and Scherr PA: Dietary intake of antioxidant nutrients and the risk of incident Alzheimer disease in a biracial community study. Jama 2002; 287(24): 3230-3237.

61. Luchsinger JA and Mayeux R: Dietary factors and Alzheimer's disease. The Lancet Neurology 2004; 3(10): 579-587.

62. Apostolova LG: Alzheimer disease. Continuum: Lifelong Learning in Neurology 2016; 22(2): 419-434.

63. McKhann GM, Knopman DS, Chertkow H, Hyman BT, Jack CR, Kawas CH, Klunk WE, Koroshetz, WJ, Manly JJ, Mayeux R and Mohs RC: The diagnosis of dementia due to Alzheimer's disease: Recommendations from the National Institute on Aging-Alzheimer's Association workgroups on diagnostic guidelines for Alzheimer's disease. Alzheimer's \& Dementia: the Journal of the Alzheimer's Association 2011; 7(3): 263-269.

64. Shaw LM, Vanderstichele H, Knapik-Czajka M, Clark CM, Aisen PS, Petersen RC, Blennow K, Soares H, Simon A, Lewczuk P and Dean R: Cerebrospinal fluid biomarker signature in Alzheimer's disease neuroimaging initiative subjects. Annals of Neurology 2009; 65(4): 403-413.

65. Humpel $\mathrm{C}$ : Identifying and validating biomarkers for Alzheimer's disease. Trends in Biotechnology 2011; 29(1); 26-32.

66. El Kadmiri N, Said N, Slassi I, El-Moutawakil B and Nadifi S: Biomarkers for Alzheimer disease: Classical and novel candidates' review. Neuroscience 2017; 370: 181190.

67. Growdon JH: Biomarkers of Alzheimer disease. Archives of Neurology 1999; 56(3): 281-283.

68. Saeed U, Swardfager W, Black SE and Masellis M: Biomarkers of Alzheimer's disease. Mental Health and Illness of the Elderly 2017; 105-139.

69. Isaac MT, Vamvakas $\mathrm{S}$ and Isaac MB: Diagnostic biomarkers for Alzheimer's disease: a regulatory view. The Lancet Neurology 2017; 16(8): 580-581.

70. Sperling RA, Aisen PS, Beckett LA, Bennett DA, Craft S, Fagan AM, Iwatsubo T, Jack CR, Kaye J, Montine TJ and Park DC: Toward defining the preclinical stages of Alzheimer's disease: Recommendations from the National Institute on Aging-Alzheimer's Association workgroups on diagnostic guidelines for Alzheimer's disease. Alzheimer's \& Dementia: the Journal of the Alzheimer's Association 2011; 7(3): 280-292.

71. Edison P, Archer HA, Gerhard A, Hinz R, Pavese N, Turkheimer FE, Hammers A, Tai YF, Fox N, Kennedy A and Rossor M: Microglia, amyloid, and cognition in Alzheimer's disease: An [11C] (R) PK11195-PET and [11C] PIB-PET study. Neurobiology of Disease 2008; 32(3): 412-419.

72. Rowe CC, Ng S, Ackermann U, Gong SJ, Pike K, Savage G, Cowie TF, Dickinson KL, Maruff P, Darby D and Smith C: Imaging $\beta$-amyloid burden in aging and dementia. Neurology 2007; 68(20): 1718-1725.

73. Klunk WE, Engler H, Nordberg A, Wang Y, Blomqvist G, Holt DP, Bergström M, Savitcheva I, Huang GF, Estrada S and Ausén B: Imaging brain amyloid in Alzheimer's disease with Pittsburgh Compound-B. Annals of Neurology 2004; 55(3): 306-319. 
74. Craig-Schapiro R, Fagan AM and Holtzman DM: Biomarkers of Alzheimer's disease. Neurobiology of Disease 2010; 35(2): 128-140.

De Toledo Ferraz Alves, TC, Ferreira LK, Wajngarten M and Busatto GF: Cardiac disorders as risk factors for Alzheimer's disease. Journal of Alzheimer's Disease 2009; 20(3): 749-763.

75. Dubois B, Feldman HH, Jacova C, DeKosky ST, Barberger-Gateau P, Cummings J, Delacourte, A, Galasko D, Gauthier S, Jicha G and Meguro K: Research criteria for the diagnosis of Alzheimer's disease: revising the NINCDS-ADRDA criteria. The Lancet Neurology 2007; 6(8): 734-746.

76. Jack CR, Albert MS, Knopman DS, McKhann GM, Sperling RA, Carrillo MC, Thies B and Phelps $\mathrm{CH}$ : Introduction to the recommendations from the National Institute on Aging-Alzheimer's Association workgroups on diagnostic guidelines for Alzheimer's disease. Alzheimer's \& Dementia: the Journal of the Alzheimer's Association 2011; 7(3): 257-262.

77. Geldenhuys WJ and Darvesh AS: Pharmacotherapy of Alzheimer's disease: Current and future trends. Expert Review of Neurotherapeutics 2015; 15(1): 3-5.
78. Francis PT, Palmer AM, Snape M and Wilcock GK: The cholinergic hypothesis of Alzheimer's disease: a review of progress. Journal of Neurology, Neurosurgery \& Psychiatry 1999; 66(2): 137-147.

79. Yiannopoulou KG and Papageorgiou SG: Current and future treatments for Alzheimer's disease. Therapeutic Advances in Neurological Disorders 2013; 6(1): 19-33.

80. Shah RS, Lee HG, Xiongwei Z, Perry G, Smith MA and Castellani RJ: Current approaches in the treatment of Alzheimer's disease. Biomedicine \& Pharmacotherapy 2008; 62(4): 199-207.

81. Chopra K, Misra S and Kuhad A: Current perspectives on pharmacotherapy of Alzheimer's disease. Expert Opinion on Pharmacotherapy 2011; 12(3): 335-350.

82. Sonkusare SK, Kaul CL and Ramarao P: Dementia of Alzheimer's disease and other neurodegenerative disorders -memantine, a new hope. Pharmacological Research 2005; 51(1): 1-17.

83. Van Marum RJ: Update on the use of memantine in Alzheimer's disease. Neuropsychiatric Disease and Treatment 2009; 5: 237-247.

\section{How to cite this article:}

Surabhi and Singh BK: Alzheimer's disease: A comprehensive review. Int J Pharm Sci \& Res 2019; 10(3): 993-00. doi: 10.13040/ IJPSR.0975-8232.10(3).993-00.

All @ 2013 are reserved by International Journal of Pharmaceutical Sciences and Research. This Journal licensed under a Creative Commons Attribution-NonCommercial-ShareAlike 3.0 Unported License.

This article can be downloaded to Android OS based mobile. Scan QR Code using Code/Bar Scanner from your mobile. (Scanners are available on Google Play store) 